2005

\title{
International Standards and the WTO
}

Steve Charnovitz

George Washington University Law School, scharnovitz@law.gwu.edu

Follow this and additional works at: https://scholarship.law.gwu.edu/faculty_publications

Part of the Law Commons

\section{Recommended Citation}

Charnovitz, Steve, "International Standards and the WTO" (2005). GW Law Faculty Publications \& Other Works. 394.

https://scholarship.law.gwu.edu/faculty_publications/394

This Article is brought to you for free and open access by the Faculty Scholarship at Scholarly Commons. It has been accepted for inclusion in GW Law Faculty Publications \& Other Works by an authorized administrator of Scholarly Commons. For more information, please contact spagel@law.gwu.edu. 


\section{International Standards and the WTO}

\section{Steve Charnovitz*}

The purpose of this paper is to provide background on the topic of international standards and their relationship to the World Trade Organization (WTO). Some international standards describe products (e.g., fish size), while others describe the processes and production methods used in making the characteristics of products. Standard-setting is intended to be a rational process that leads to technically preferable solutions. As two commentators explain, the influence of standards

derives from the truth presumably embodied in science and technique, from the righteousness presumably embodied in the principles of governance by which the standards bodies operate (equality, fairness, nonpartisanship), and from the presumed self-interest of the lower-level actors that comprise them. ${ }^{1}$

While standards have an enormous potential for increasing efficiency and thereby boosting economic growth, concerns exist as to whether the WTO's utilization of international standards may exacerbate the disparities between rich and poor countries. The problem is that developing countries lack capacity to reap all the benefits of international standards. To some extent this problem has already been acknowledged, and governments are now stepping up efforts to provide more technical assistance to developing countries.

The paper has seven parts. Part I explores the meaning of the term "international standard" and explains why a broad definition is adopted in this study. Part II introduces a typology for international standards, particularly as they relate to the WTO. Part III discusses why international standards are important to economic development and growth. Part IV examines the WTO

\footnotetext{
*This study was prepared in May 2002 as a background paper for the Global Forum on Trade, Environment and Development. Thanks to Veena Jha, Gabrielle Marceau, Jan Martinez, Sylvia Ostry, Shishir Priyadarshi, Larry Susskind, and Edith Brown Weiss for their helpful comments. (C) Steve Charnovitz.
}

${ }^{1}$ Thomas A. Loya \& John Boli, Standardization in the World Polity: Technical Rationality over Power, in ConstruCting World Culture 169, 193 (John Boli \& George M. Thomas, eds., Stanford University Press, 1999). 
provisions that relate to international standards using the categories of: re-legislation, requirement, recommendation, exemption, presumption, technical assistance, and cooperation. Part $\mathrm{V}$ provides a brief review of WTO implementation of standards-related provisions through WTO committees. Part VI describes key standard-setting organizations that promulgate standards relating to trade. Part VII concludes.

\section{What Are International Standards?}

The term "international standard" has a variety of meanings in conventional usage. In its stiffest form, it can mean an international rule expressed in a treaty obligation. For example, the panoply of United Nations (U.N.) human rights treaties are often said to embody international standards. In its mildest form, a standard might be nothing more than a common or prevailing trend in the marketplace.

As used in this paper, an international standard is a norm for market-based activity. The norm can be expressed directly, or as a rule for how governments should seek to influence (or not influence) private behavior. An international standard has two essential attributes. One is that it has been prescribed or recommended by an institution set up for that purpose. The other is that the institution must be international in the sense that it involves participation of individuals from more than two countries.

Standards can be set by both government-driven and nongovernmental processes. Many international standard-setting institutions are intergovernmental organizations. For example, the Codex Alimentarius Commission - which promulgates food standards to be used by governmentsis an entity established by the U.N. Food and Agriculture Organization (FAO) and the World Health Organization (WHO). Many standard-setting institutions are not intergovernmental. For example, the Marine Stewardship Council is a nongovernmental organization (launched by a partnership of Unilever and WWF) that sets standards for responsible fishery and marine ecosystem practices, and 
offers a label to qualifying companies. Many standards are devised by industry groups and become codes of good practice.

International standard-setting processes have a variable openness to stakeholder input. When standard-setting is government driven, it often provides opportunities for private participation. When standard-setting is privately driven, it will be done in the context of applicable law, and may entail government and other stakeholder input. Nevertheless, the degree of transparency and openness of any standard-setting process will always be a point of tension with social or economic actors who feel excluded or who believe the values they cherish are being under-weighted.

Because most of the standard-setting institutions discussed in this paper are private organizations, they do not have any jurisdiction to prescribe standards to governments or to private economic actors. Thus, the pull for following the standard is not legal compulsion, but rather enlightened self-interest. Of course, once adherence to a certain standard becomes expected in the marketplace, a producer may feel economically motivated to follow it (e.g., international accounting standards). Often standards are accompanied by labels, marks, or seals that rely on information as a means of reinforcing the standard.

This double-edged quality of a standard in private organizations also exists in intergovernmental institutions. Just as a private actor may be pressured into following an industry standard, a nation state may be pressured into ratifying a treaty. In both instances, the benefit of inculcating the norm is viewed as outweighing the cost of autonomy. As noted above, treaty-based organizations are not limited to prescribing rules. They can also recommend certain standards of behavior for government parties. For example, the WTO Agreement on Textiles and Clothing (art. 1.5) provides that in order to facilitate the integration of the textiles and clothing sectors in regular trade rules, the WTO Members "should allow for continuous autonomous industrial adjustment and increased competition in their markets." The United Nations Agenda 21 contains nearly 300 pages 
of recommendations, mainly directed at governments (but some also directed at international organizations and private actors).

From the perspective of the government considering such recommendations, these provisions may have a similarly low level of authoritativeness akin to a standard set by an industry association from the perspective of a particular corporation. In at least one of the examples given above - the Agreement on Textiles and Apparel-implementation has been poor. In fact, it may be that multinational corporations take industry-wide standards more seriously than the richest governments have taken the recommendation that they allow for continuous adjustment to greater textile and clothing trade.

In summary, this paper embraces a broad definition of standards to include purely public, purely private, and mixed public-private standard-setting. It is this variable geometry of public and private initiative that is the most salient feature of contemporary international standards. Using a broad definition is also important because the WTO can interact with this full range of activities. Part IV will elaborate on this actual and potential interplay between WTO rules and international standards.

The broad definition pursued here should be contrasted with the narrower definition of "standard" used in the WTO Agreement on Technical Barriers to Trade (TBT). In TBT, a standard is defined as a:

Document approved by a recognized body, that provides, for common and repeated use, rules, guidelines or characteristics for products or related processes and production methods, with which compliance is not mandatory. It may also include or deal exclusively with terminology, symbols, packaging, marking or labelling requirements as they apply to a product, process or production method. ${ }^{2}$

\footnotetext{
${ }^{2}$ Agreement on Technical Barriers to Trade, Annex 1, para. 2 (emphasis added). The document can be approved on a consensus basis, or on a non-consensus basis. Id.
} 
In TBT parlance, a standard is distinguished from a "technical regulation" which is defined as a "Document which lays down product characteristics or their related processes and production methods, including the applicable administrative provisions, with which compliance is mandatory." ${ }^{3}$ Thus, the difference between a TBT standard and a TBT regulation is that the former is voluntary and the latter is mandatory.

This paper does not follow the TBT definitions for three reasons. First, although voluntary standards are important, the mandatory standards, such as those in multilateral environmental agreements (MEAs), are a central part of the "trade, environment and development" debate and need to be discussed here. A second reason is the TBT definition only addresses product standards and their "related" processes and production methods. ${ }^{4}$ Thus, TBT omits the putatively unrelated processes such as a standard for shrimp harvesting that does not injure turtles. ${ }^{5}$ Such standards have tremendous importance in the real world. A third reason for not following the TBT definition is that it only deals with "recognized" bodies. The problem with this limitation is that new, unrecognized bodies that seek to harmonize standards may indeed have an impact in a highly interdependent world economy.

In Part II, the paper will try to make more concrete the broad definition of standard as employed herein. To do so, a typology of international standards will be presented.

\section{A Typology of International Standards}

In thinking about better standard-setting, one can distinguish several kinds of international standards set at the international level. Consider the following typology of the norms espoused:

\footnotetext{
${ }^{3}$ Ibid., para. 1 (emphasis added).

${ }^{4}$ Ibid. It is clear, however, that the TBT applies both to products and to "methods of production." See TBT art. 2.12.

${ }^{5}$ The meaning of "related" in the TBT definition of "technical regulation" and "standard" has not yet been adjudicated. Panels could adopt a broad definition of related to embrace all sustainability standards.
} 
1. Norms for governments.

a. About relations with other governments.

b. About regulation of private actors.

2. Norms for economic actors.

a. About products.

b. About processes and product methods (PPMs).

c. About corporate behavior.

3. Norms for international standard-setting institutions.

4. Norms for national standard-setting institutions.

a. About substance.

b. About process.

In every category, the norms can vary from prescriptive to exhortative. This typology is discussed below.

1. Norms for governments. Some norms address the relationship of governments (or states) to each other. For example, customary international law addresses the recognition of states and the delineation of maritime boundaries. Such rules are not treated as a standard in this paper because no private actor is in the picture.

The larger body of norms address how governments deal with private actors. This can be part of customary international law; for example, the law governing expropriation and compensation. Far more common is the use of treaties to proscribe certain behavior by governments. That is what WTO rules do. They put disciplines on governmental measures such as import bans, regulations, subsidies, and taxes. In some instances, the private actor is only implicit in the rule. For example, the most-favored nation rule (art. I) in the General Agreement on Tariffs and Trade (GATT) states that any advantage or favor accorded to a product of one country must be accorded to the like product of any contracting party. In other instances, the private actor is explicitly the beneficiary of the WTO rule. For example, the Customs Valuation Agreement (art. 11.1) directs governments to give importers the right to appeal a determination of customs value. 
2. Norms for economic actors. Like most treaties, the WTO does not prescribe standards directly for economic actors. Rather, the WTO affects individuals indirectly through rules applied to governments. The closest the WTO may get to a standard for individuals is the condemnation of injurious dumping in GATT rules (art. VI:1). Dumping is a pricing strategy of producers; it is not done by governments.

Increasingly, international organizations are writing standards that apply to individuals as well as governments. For example, the International Labour Organization's Tripartite Declaration of Principles Concerning Multinational Enterprises and Social Policy recommends actions to multinational enterprises, employers, workers, and to governments. Another example is the U.N. Security Council Resolution 1306 (in 2000) on Sierra Leone which, inter alia, encourages the diamond industry to develop methods to control illicit trade in diamonds. The World Diamond Council has responded to this and other U.N. resolutions by establishing a control process for diamond exports and imports, including a "conflict-free trade zone." Another example is the FAO Code of Conduct for Responsible Fisheries which is a voluntary code that applies to states, international organizations, fishers, and those engaged in processing and marketing fish. ${ }^{7}$

The United Nations also proposes voluntary standards exclusively for the private sector. Most notably, the new U.N. Global Compact propounds nine principles on human rights, labor, and environment for participating corporations.

Standards for economic actors can be of three types: product standards, PPMs, or corporate behavior. ${ }^{8}$ Product standards provide specifications for the product itself. They are commonly set by

\footnotetext{
${ }^{6}$ See www.worlddiamondcouncil.com.

${ }^{7}$ See www.fao.org/fi.

${ }^{8} \mathrm{~A}$ recent paper prepared by analysts at the International Institute for Environment and Development sets out four types of standards - relating to quality, safety, authenticity, and goodness of the production process. Bill
} 
governments (e.g., a pesticide tolerance) or recommended by private organizations. PPMs prescribe the conditions under which a product is to be manufactured, grown, harvested, mined, or transported. They are commonly set by governments, and are sometimes agreed to by a treaty. ${ }^{9}$ For example, the prohibition (art. 3.1) on the transhipment of driftnet-caught fish-found in the Wellington Convention for the Prohibition of Fishing with Long Driftnets in the South Pacific Ocean - has been implemented in national law. Another example is the WTO Agreement on TradeRelated Aspects of Intellectual Property Rights (TRIPS) which requires governments to establish a procedure whereby an individual rights holder can block the import of a good lacking a valid trademark or copyright (see art. 51).

PPMs are also recommended by private organizations. For instance, the Forest Stewardship Council provides a FSC logo for forest products to guarantee the buyer that the wood comes from a well-managed forest, based on the International Principles and Criteria of Forest Stewardship. Corporate behavior or performance standards are more general than a PPM and define the behavior of the corporation broadly. Some standards are prescribed by governments (e.g., corporate governance law), and many others are prescribed in financial market institutions or private associations. One example of a privately-set standard for corporate environmental behavior is the Valdez Principles. Among these principles is that at least one member of the corporate board of directors be a person qualified to represent environmental interests.

Vorley, Dilys Roe \& Steve Bass, "Standards and Sustainable Trade: A Sectoral Analysis for the Proposed Trade and Innovation Centre (STIC)," April 2002, at 6.

${ }^{9}$ The status of PPMs under WTO law is contentious. For a recent study of the law, see Steve Charnovitz, The Law of Environmental "PPMs" in the WTO: Debunking the Myth of Illegality, 27 YALE JOURNAL OF INTERNATIONAL LAW 59 (2002). 
3. Norms for International Standard-Setting Institutions. Supervision of other standardsetting organizations is an emerging practice in the TBT Agreement. This is done via obligations such as that

\begin{abstract}
Members shall take such reasonable measures as may be available to them to ensure that international standardizing bodies and international systems for conformity assessment are organized and operated in a way which facilitates active and representative participation of relevant bodies in all Members, taking into account the special problems of developing country Members (art. 12.5).
\end{abstract}

This provision indirectly sets a norm for standardizing bodies in regard to participation. Another important provision appears in the TBT Code of Good Practice for the Preparation, Adoption and Application of Standards ("TBT Code"), which is Annex 3 of the TBT Agreement. According to the TBT Code, regional standardizing bodies (consisting of more than one country) shall make every effort to avoid duplication of, or overlap with, the work of relevant international standardizing bodies (para. $\mathrm{H}$ ). This provision demonstrates the potential of the WTO to prescribe rules extrajurisdictionally.

The TBT Code also seeks to supervise how standard-setting bodies at the national level participate at the international level. Specifically, the Code suggests that all bodies in a territory interested in a particular subject matter participate through "one delegation" at the international body (para. G).

4. Norms for National Standard-Setting Institutions. The WTO prescribes many rules for national standard-setting. They are both substantive and procedural. The Agreement on the Application of Sanitary and Phytosanitary Measures (SPS) entails many substantive standards. For example, it requires that government measures be based on scientific principles and not maintained without sufficient scientific evidence (art. 2.2). More common in the WTO are standards on procedure. For example, the TBT Agreement requires governments to publish a notice of new technical regulations at an early appropriate stage in such a manner as to enable interested parties 
(including non-state actors) to become acquainted with it (art. 2.9.1). The Annex on

Telecommunications of the General Agreement on Trade in Services (GATS) requires governments to make available the specifications for technical interface with public communications transport networks (para. 4).

The most ambitious attempt in the WTO to oversee national standard-setting is the TBT Code. According to TBT rules (art. 4.1), central government standardizing bodies must comply with the TBT Code. While other standardizing bodies — such as local government bodies or nongovernmental bodies - are not required to comply, the WTO directs central governments to take reasonable measures as may be available to them to ensure that such bodies do comply (art. 4.1). Furthermore, TBT holds central governments responsible when the trade interests of a complaining country are significantly affected by the standards set by a subnational or nongovernmental body (art. 14.4). The TBT Code has been accepted by 138 standardizing bodies in 94 countries. These bodies are split evenly between governmental and nongovernmental.

The TBT Code blends substantive and procedural provisions. For example, standards shall not be prepared, adopted or applied with a view to, or with the effect of, creating unnecessary obstacles to international trade (para. E). In many instances, the Code has stricter disciplines than exist in the core TBT rules. For example, the Code states that standardizing bodies shall make every effort to achieve a "national consensus" on the standards they develop (para. H). The TBT Code also contains cutting-edge participation provisions. Specifically, it provides that before adopting a standard, the body shall allow a period of at least 60 days for comments on a draft standard by interested parties in any WTO Member country (para. L). The body is further directed to take these comments into account and, if requested, to reply as promptly as possible (para. N). Another rule is that standardizing bodies shall provide adequate opportunities for consultation with other standardizing bodies (para. Q). 
In summary, a typology is presented to point out the four different types of international standard-setting engaged in (or potentially engaged in) by the WTO, other international organizations, or private groups. These activities are interrelated, both vertically (e.g., governments and international organizations) and horizontally (e.g., among international organizations). So far, the paper has discussed the nature of international standards. Now it is time to consider why they are used.

\section{Why International Standards Are Important}

Standards can allow markets to operate more efficiently. They do so by reducing information and bargaining costs for producers and consumers, and by obviating duplicative systems. An economy without standards would be highly inefficient. For some standards, the actual definition is not as important as the fact that it becomes the conventional practice, for example, paper size. $^{10}$

International economic, environmental, and social standards are needed because humans live in an increasingly borderless world. The ecosystem, human health, safety and security, commerce, financial transactions, and information in one country all depend on activities in other countries. Any exporter knows the costs of inconsistent national documentation standards, and the value of harmonization. Any traveler knows the costs of not being able to use her telephone in another country. Progress toward achieving common standards inside different countries may be a salutary effect of globalization.

More analytically, one can point to four ways in which international standards can enhance world economic welfare, and particularly the welfare of low-income countries. First, an international standard can help avoid the inefficiency of segmented national markets following

\footnotetext{
${ }^{10}$ Tom Rotherham, “Market Access, Sustainable Management Standards and Technical Equivalence," May 2002 , at 3 .
} 
different standards. This benefit can be especially important for countries with small internal markets like many developing countries. Second, a widely subscribed international standard can prevent conflicts about differences in standards. For well over a century, trade disputes about sanitary standards have led to conflicts that sometimes spill over into other bilateral issues. Smaller countries will always be at a disadvantage in such disputes, and therefore will have the most to gain - for example, from a system of international food and veterinary standards. Third, an international standard might raise the conditions in countries that otherwise fall below it. Assuming that the international standard is set appropriately, the elevation of standards will help the laggard country. In some instances, there will have already been unilateral pressure on a country to raise its standards, but that pressure is sometimes resisted as being paternalist or imperialist. By contrast, low-standard countries might be more willing to embrace a truly international standard. Fourth, the movement to international standards may lead to greater efforts at capacity building for developing countries. Several WTO agreements that set standards call for more technical assistance. ${ }^{11}$ In reality, however, very little of such assistance has been delivered by the WTO, and so that opportunity for raising world welfare has been neglected.

Of course, international standards are not guaranteed to raise welfare. They can only do so if the standard is set at an appropriate level. An excessive standard that is too high for most of the world could actually retard economic growth and lower incomes. Conversely, an improperly low standard could be counterproductive if it dragged down environmental or social conditions. That is why many standards are prescribed (or recommended) as minimums. The need to clarify that international standards should not retard national standards became apparent in the drafting of the constitution of the International Labour Organization (ILO) in 1919. The ensuing treaty stated that

\footnotetext{
${ }^{11}$ Agreement on Technical Barriers to Trade, arts. 11, 12.7; Agreement on the Application of Sanitary and Phytosanitary Measures (SPS), art. 9; Agreement on Trade-Related Aspects of Intellectual Property Rights (TRIPS), arts. 66.2, 67.
} 
in no case shall any ILO member be asked to lessen the protection afforded by its existing legislation, as the result of the adoption of an international convention or recommendation. ${ }^{12}$ Similar provisions were included in many subsequent treaties.

Some economists would caution against any international standard on the grounds that each jurisdiction should fine-tune its own standards that will be optimal for it. This view springs from the "Tiebout" economic model which presumes that horizontally arrayed jurisdictions compete to attract residents using different tax and benefit structures. While a simplified model might lead to efficient outcomes in each jurisdiction, the model has little value in a world with market failure, transborder externalities, barriers to mobility, and economies of scale. ${ }^{13}$ Nevertheless, there is much truth in the shibboleth that one size does not fit all, and so standardization projects should always consider the value of permitting a diversity of standards and also of encouraging entities to engage in some regulatory competition.

Fair competition will not be possible, however, if the competitors are of markedly different size. Large economies will tend to dominate standard-setting processes because of the value of their markets. An even more troublesome problem can occur if a large market, like the United States or the European Community, torques its standards in a way so as to give advantage to domestic producers. That danger establishes another reason to promote international standards - namely, that standards in large countries might reflect a competitiveness strategy rather than a technically or scientifically driven standard.

In practice, standard-setting is almost never divorced from competitiveness considerations. Standards can easily become barriers to entry for competitors. This problem must be recognized and

\footnotetext{
${ }^{12}$ Treaty of Versailles, art. 405. The current provision is in the Constitution of the ILO, art. 19(8).

${ }^{13}$ For a discussion, see Daniel C. Esty \& Damien Geradin, Regulatory Co-opetition, in REGULATORY COMPETITION AND ECONOMIC INTEGRATION 30, 32-40 (Daniel C. Esty \& Damien Geradin eds., Oxford University Press, 2001).
} 
addressed head-on because even when standards increase worldwide income, they may exacerbate inequities in the distribution of income between rich and poor countries. Therefore, affirmative steps will be needed to assist developing countries in the standard-setting process. Recently, analysts have proposed the establishment of a Sustainable Trade and Innovation Centre to do so. ${ }^{14}$ Among its tasks would be to set out best practices for standard-setting, certification, and accreditation; to promote harmonization of standards schemes; and to conduct research on the information and other costs being imposed on standards "takers."

\section{WTO Provisions on International Standards}

Although the WTO is best known for propounding its own rules, the WTO agreements draw from and interrelate with many other founts of international standards. Part IV discusses the interplay between WTO rules and international standards.

1. Re-legislation. Some WTO agreements incorporate a specific standard from another organization and transform it into a WTO obligation. For example, the TRIPS Agreement requires adherence to listed provisions of the Paris Convention of 1967 for the Protection of Industrial Property, the Berne Convention of 1971 for the Protection of Literary and Artistic Works, and the Treaty on Intellectual Property in Respect of Integrated Circuits. ${ }^{15}$ The Agreement on Agriculture (art. 10.4(b)) requires governments to carry out international food aid transactions in accordance with the FAO Principles of Surplus Disposal and Consultative Obligations. The WTO Agreement on Preshipment Inspection (PSI) requires that quality and quantity inspections be performed in

\footnotetext{
${ }^{14}$ Vorley et al., supra note 8.

${ }^{15}$ TRIPS arts. 2.1, 9, 35 .
} 
accordance with the standards defined in the purchase agreement with the default being "relevant international standards" (art. 2.4). ${ }^{16}$

2. Requirement. One WTO agreement appears to require the use of international standards. The TBT Agreement (art. 2.4) directs governments to use international standards as "a basis for" a technical regulation except when such standards "would be an ineffective or inappropriate means for the fulfillment of the legitimate objectives pursued, for instance because of fundamental climatic or geographical factors or fundamental technological problems." This provision has not been interpreted yet by the WTO judiciary so it is unclear whether panels will seek to review the reasons a government gives for not basing a national standard on an international standard. ${ }^{17}$ The meaning of "a basis for" will also be contentious as will the allocation of the burden of proof. Whether this TBT provision will be implemented more as a recommendation than a requirement remains to be seen.

The TBT Agreement also requires governments to use international standards on conformity assessment. Specifically, TBT (art. 5.4) calls for using international standards as a basis for national conformity assessment procedures. Derogations are permitted when international guides or recommendations are inappropriate for the government concerned for reasons such as national security, the protection of human health or safety, or the environment.

3. Recommendation. Some WTO agreements recommend adherence to a standard from another organization. For example, SPS directs governments to "base" their sanitary and phytosanitary measures on "international standards, guidelines, or recommendations" (art. 3), but

\footnotetext{
${ }^{16}$ Furthermore, the PSI Agreement defines an international standard as a "standard adopted by a governmental or non-governmental body whose membership is open to all [WTO] Members [and] one of whose recognized activities is in the field of standardization." PSI Agreement, Footnote 2. It is unclear what "open" means here. The WTO itself is ostensibly open to new members, but in practice many governments continue to be denied membership.

${ }^{17}$ The first panel report was issued on May 29, and is not discussed here. European Communities - Trade Description of Sardines, WT/DS231/R.
} 
notes that they may use higher standards if there is scientific justification or if the government determines that a higher level is more appropriate in accordance with SPS rules. ${ }^{18}$ In the $E C-$ Hormones case, the Appellate Body explained that this rule does not require that SPS measures conform to international standards. ${ }^{19}$ To facilitate the implementation of this rule, the WTO Committee on Sanitary and Phytosanitary Measures is directed to work with other international organizations in order to establish a list of international SPS standards that have a major trade impact (art. 12.4). The Agreement on Agriculture also employs recommendations. For example, it suggests (art. 10.4(c)) that when governments deliver international food aid, it "shall be provided to the extent possible in fully grant form or on terms no less concessional than those provided in Article IV of the Food Aid Convention 1986." Another example of a recommendation can be found in the TBT provision on equivalence (art. 2.7) which states that "Members shall give positive consideration to accepting as equivalent technical regulations of other Members, even if these regulations differ from their own, provided they are satisfied that these regulations adequately fulfil the objectives of their own regulations."

4. Exemption. Some WTO agreements accord an exemption to a national measure that is based on an international standard. By receiving such an exemption, a disputed national measure would not be adjudged a violation of WTO rules. The TRIPS Agreement does this in a few provisions. For instance, it provides an exemption from the most-favored-nation discipline for discriminatory treatment derived from international agreements on judicial assistance or law enforcement (art. 4). Similarly, TRIPS provides an exemption (art. 5) from the national treatment and most-favored-nation disciplines for discriminatory treatment derived from agreements in the

\footnotetext{
${ }^{18}$ This provision would seem to suggest that international standards are a floor, but in practice no government has complained that another government's standards are too low.

${ }^{19}$ EC Measures Concerning Meat and Meat Products (Hormones), WT/DS26/AB/R, para. 165 (16 January 1998).
} 
World Intellectual Property Organization (WIPO) relating to the acquisition or maintenance of intellectual property rights. Like TRIPS, other WTO agreements contain exemptions. For instance, the SCM Agreement (Annex I, para. k) prohibits certain below-market export credit practices, but exempts export credit practices in conformity with the international undertaking on official export credits sponsored by the Organisation for Economic Co-operation and Development (OECD). The GATS (arts. XIV(e), XXII:2) permits discrimination resulting from an international agreement on the avoidance of double taxation. The GATT, GATS and TRIPS provide a broad exception for actions in pursuance of obligations under the United Nations Charter for the maintenance of international peace and security. ${ }^{20}$

5. Presumption. Some WTO agreements accord a favorable presumption to a national measure based on an international standard. With such a presumption, a disputed national measure would be much less likely to be adjudged a violation of WTO rules. For example, the SPS Agreement (art. 3.2) provides that sanitary and phytosanitary measures conforming to international standards shall be "presumed" to be consistent with the relevant provisions of the SPS Agreement and the GATT. The TBT Agreement states that when a national technical regulation has a legitimate objective and is in accord with relevant international standards, it shall be "rebuttably presumed" (art. 2.5) not to create an unnecessary obstacle to trade (and thus violate TBT). Under the GATS (art. VI:5), governments are prohibited from applying licensing and qualification requirements in a manner that would impair trade commitments and violate other rules; but in enforcing this provision, account is to be taken of any relevant international standards being applied.

No opportunity to apply the presumptions under the above provisions has yet occurred in WTO dispute settlement. The only relevant judicial decision is the EC-Computer Equipment case

\footnotetext{
${ }^{20}$ GATT art. XXI(c); GATS art. XIV bis:1(c); TRIPS art. 73(c).
} 
where the Appellate Body held that in interpreting national tariff schedules, a decision of the World Customs Organization could be relevant as constituting subsequent practice of the parties to the dispute. $^{21}$

6. Technical Assistance. Some WTO agreements state a commitment of governments to deliver technical assistance to developing countries so as to promote the use of international standards. For example, the TBT agreement (art. 11.2) calls for technical assistance on the establishment of national standardizing bodies and participation in international standardizing bodies. TBT also calls for assistance to developing countries on the establishment of the institutions and legal framework they need to participate in international or regional systems for conformity assessment (art. 11.6). The SPS Agreement has analogous provisions. For example, it directs governments to encourage and facilitate the active participation of developing countries in relevant international organizations (art. 10.4).

Unfortunately, efforts to deliver such technical assistance have been weak. One of the outcomes of Doha was that the WTO was tasked with stepping up its overall technical assistance, but this is likely to be focused on trade negotiating assistance. At Doha, the several standard-setting organizations related to SPS announced an initiative, along with the World Bank, to boost participation by developing countries in standard-setting. ${ }^{22}$

7. Cooperation with Other International Organizations. Several WTO agreements call for involvement in or cooperation with other international organizations that set rules or standards. These provisions are summarized in the chart below:

\footnotetext{
${ }^{21}$ European Communities - Customs Classification of Certain Computer Equipment, WT/DS62/AB/R, para. 90 (5 June 1998).

${ }^{22}$ Agencies to boost developing countries' participation in setting food safety and related norms, WTO Presse/254 (11 November 2001).
} 


\begin{tabular}{|c|c|}
\hline Agreement & Provision \\
\hline $\begin{array}{l}\text { Sanitary and } \\
\text { Phytosanitary Measures } \\
\text { (SPS) }\end{array}$ & $\begin{array}{l}\text { Directs governments to play a full part in the Codex Alimentarius } \\
\text { Commission, the International Office of Epizooties, and the } \\
\text { International Plant Protection Convention (art. 3.4). These are } \\
\text { designated as the relevant international organizations (Annex A). } \\
\text { Directs the WTO Committee on SPS to monitor the process of } \\
\text { international harmonization and coordinate efforts with relevant } \\
\text { international organizations (art. 3.5). } \\
\text { Permits the WTO Committee to invite the relevant international } \\
\text { organizations to examine specific matters with respect to a } \\
\text { particular standard (art. 12.6). When a government does not apply } \\
\text { an international standard, it shall provide the Committee an } \\
\text { indication of the reason why and, in particular, whether it } \\
\text { considers the standard not stringent enough (art. 12.4). The } \\
\text { Committee then may invite the relevant organization to examine } \\
\text { the reason for non-use given to the Committee (art. 12.6). }\end{array}$ \\
\hline $\begin{array}{l}\text { Technical Barriers to } \\
\text { Trade (TBT) }\end{array}$ & $\begin{array}{l}\text { Directs governments to play a full part in the preparation by } \\
\text { international standardizing bodies of international standards for } \\
\text { products (art. 2.6). } \\
\text { Directs governments to assure that international standardizing } \\
\text { bodies consider requests to develop international standards of } \\
\text { special interest to developing countries (art. 12.6). } \\
\text { WTO Secretariat is to reach an understanding with the } \\
\text { International Organization for Standardization (ISO) to establish } \\
\text { a joint information system (Marrakesh Decision). }\end{array}$ \\
\hline $\begin{array}{l}\text { Agreement on Trade- } \\
\text { Related Aspects of } \\
\text { Intellectual Property } \\
\text { Rights (TRIPS) }\end{array}$ & $\begin{array}{l}\text { Directs the Council for TRIPS to establish appropriate } \\
\text { cooperation with bodies of the World Intellectual Property } \\
\text { Organization (WIPO). }\end{array}$ \\
\hline $\begin{array}{l}\text { Agreement on Rules of } \\
\text { Origin }\end{array}$ & $\begin{array}{l}\text { Establishes a work program to harmonize rules of origin in } \\
\text { conjunction with the Customs Co-operation Council (art. 9). }\end{array}$ \\
\hline $\begin{array}{l}\text { Agreement on } \\
\text { Implementation of } \\
\text { Article VII of GATT } \\
1994\end{array}$ & $\begin{array}{l}\text { Establishes a Technical Committee on Customs Valuation under } \\
\text { the auspices of the Customs Co-operation Council (art. 18). }\end{array}$ \\
\hline
\end{tabular}




\begin{tabular}{|l|l|}
\hline GATT 1994 & $\begin{array}{l}\text { Directs the organization to seek cooperation with the } \\
\text { International Monetary Fund (art. XV:1). } \\
\text { Mandates acceptance of an IMF determination on a serious } \\
\text { decline in monetary reserves (art. XV:2). } \\
\text { Directs governments to collaborate through international } \\
\text { harmonization and adjustment of national policies (art. } \\
\text { XXXVIII:2(e)). }\end{array}$ \\
\hline $\begin{array}{l}\text { General Agreement on } \\
\text { (GATS) in Services }\end{array}$ & $\begin{array}{l}\text { Wherever appropriate, directs governments to cooperate with } \\
\text { relevant international organizations toward the establishment of } \\
\text { common international standards and criteria for recognition, and } \\
\text { common international standards for the practice of service trades } \\
\text { and professions (art. VII:5). }\end{array}$ \\
$\begin{array}{l}\text { Directs governments to seek global compatibility of } \\
\text { telecommunications networks by promoting standards in relevant } \\
\text { international bodies such as the International } \\
\text { Telecommunications Union and the ISO (Annex on } \\
\text { Telecommunications, para. 7(a). }\end{array}$ \\
\hline
\end{tabular}

This chart shows how the WTO embraces international standards in many areas. So far, however, the WTO has not done so with respect to the environment.

\section{WTO Implementation on International Standard-setting}

This section provides a brief overview of the key activities of the WTO regarding international standards. In particular, I will discuss the Committees on TBT and SPS, and the Council for Trade in Services.

1. TBT Activities. The Committee has engaged in many activities to promote international standard-setting and compliance with TBT rules. Several standard-setting organizations have made presentations, such as the FAO, the Codex Alimentarius Commission, the International Office of Epizooties (OIE), the International Telecommunications Union (ITU), the OECD, and the International Organization of Legal Metrology (OIML), the International Electrotechnical Commission (IEC), and the ISO. Most of these are intergovernmental organizations, but the latter 
two are not. In Committee deliberations, some governments have pointed out that the obligation to use international standards is made more difficult by the diversity of international standard-setting institutions. As a remedy, Brazil has suggested a new principle of "singularity," in which only one organization would be recognized in each area of standardization. ${ }^{23}$ Other concerns expressed were that the procedures used to develop international standards may lack full participation of developing countries. Several governments advocated the adoption of a TBT Committee Decision on Principles for the Development of International Standards, and this has now been done. Attaining such disciplines was also endorsed by ISO and the IEC.

The TBT Committee Principles are meant to guide international standard-setting organizations. ${ }^{24}$ The listed principles include: Transparency, Openness, Impartiality and Consensus, Effectiveness and Relevance ${ }^{25}$, Coherence, and a Development Dimension. As of now, the principles are non-binding, but there have been suggestions that adherence to these principles be made a condition for recognizing a particular set of international standards in the WTO.

The standardizing institutions have not questioned the audacity of the TBT Committee in propounding these principles, but there would certainly be grounds for doing so. The problem is not the substance of the principles; most of them reflect conventional wisdom on good governance. The problem is that the WTO itself does not honor these principles in its own activities. Consider, for example, the Transparency principle, which calls for:

\footnotetext{
${ }^{23}$ Communication from Brazil, G/TBT/W/140 (28 July 2000). Brazil's paper gives little attention to value of singularity versus the value of competition.

${ }^{24}$ Decision of the Committee on Principles for the Development of International Standards, Guides and Recommendations with relation to Articles 2, 5 and Annex 3 of the Agreement, G/TBT/9, Annex 4 (13 November 2000).

${ }^{25}$ Effectiveness and relevance means, inter alia, that standards should not distort the global market, have adverse effects on fair competition, or stifle innovation and technological development. In addition, standardizing bodies should improve communication with the WTO. The Principles do not define "fair competition."
} 
The publication of a notice at an early appropriate stage, in such a manner as to enable interested parties to become acquainted with it, that the international standardizing body proposes to develop a particular standard;

and

The provision of an adequate period of time for interested parties in the territory of at least all members of the international standardizing body to make comments in writing and take these written comments into account in the further consideration of the standard.

Many economic and social actors would like the WTO to achieve such transparency during the new multilateral negotiations initiated at Doha. Nevertheless, the WTO provides no opportunity for interested parties to comment on proposed negotiating texts. Furthermore, even the non-negotiating activities of WTO committees are conducted without transparency. For instance, the TBT Committee meeting that adopted these Principles was closed to the public, as all WTO committee meetings are. Civil society organizations had no opportunity to provide input into the development of these Principles. Even the minutes of the TBT Committee meetings remain unavailable to the public for about a year.

2. SPS Activities. The Committee has engaged in many activities to promote international standard-setting and compliance with SPS rules. Several standard-setting organizations participate as regular observers, such as the FAO, the WHO, the Codex Alimentarius Commission, the Secretariat of the International Plant Protection Convention, the Inter-American Institute for Cooperation on Agriculture, and the OIE. The SPS Committee has adopted a Procedure to monitor the process of international harmonization, in which some standard-setting organizations make reports to the Committee on their activities. Within the Committee, a major topic of discussion is the difficulty that poor countries face in actively participating in the development of international standards. In March 2001, the WTO hosted a workshop for developing countries.

In October 2001, the SPS Committee approved a decision on the implementation of SPS Article 4 which addresses the determination of equivalence between SPS measures in different 
countries. ${ }^{26}$ The Committee asked the Codex Alimentarius Commission to complete its work on equivalence as expeditiously as possible. The Committee also encouraged the OIE to elaborate guidelines on equivalence. The making of such recommendations to other organizations is an interesting development in WTO practice.

3. GATS Activities. The GATS Council and its subsidiary bodies have begun to examine international standards, but little information on these activities is publicly available. In October 2001, the Committee on Trade in Financial Services held an informal briefing session to hear reports from the Basel Committee on Banking Supervision, the International Organization of Securities Commissions, and the International Association of Insurance Supervisors. The GATS Council is considering a WTO memorandum of understanding with the Universal Postal Union and the International Civil Aviation Organization.

\section{Overview of Key Standard-setting Organizations}

Having discussed how the WTO injects its norms into other standard-setting institutions, this paper will now describe some of the bodies in what the TBT Agreement calls the "international standardization community." Part VI provides a brief overview of seven standard-setting organizations. Although not discussed herein, there is scientific participation in all of these organizations.

1. International Telecommunications Union (ITU). The ITU was founded in 1865 by Member States to promote the development of a telegraph network. The ITU is now a specialized agency of the United Nations. Besides the Member States, the ITU also recognizes Sector Members which are operating agencies in various countries. In addition, the ITU is open to cooperation with other international organizations and nongovernmental organizations (NGOs). The ITU has 14

\footnotetext{
${ }^{26} \mathrm{G} / \mathrm{SPS} / 19$ (19 September 2001).
} 
study groups that devise standards. At a late stage in the process, standards have to be approved by 70 percent of the Member States. The final step is for a new standard to be adopted by consensus. Although it is an intergovernmental organization, the ITU does not make its standards binding. They tend to be complied with, however, because of technical demands for inter-connectivity.

2. International Electrotechnical Commission (IEC). The IEC is a transnational organization established in 1906 to promote cooperation on electrical standardization. Participation is by country with the representation through a national committee. The national committee is required by the IEC to have open access and balanced representation of the private and public electrotechnical actors within the country. A proposal for a new standard typically originates in a national committee and this is referred to the appropriate IEC Technical Committee. The IEC processes are open to broad participation. Besides the national committees, there is participation by international organizations, and international NGOs. Approval of new standards occurs through a complex voting process that requires a two-thirds vote in favor and not more than one-quarter against. Going through the entire process takes about five years.

3. International Office of Epizooties (OIE). The OIE was established by governments in 1924 to harmonize health requirements for the international trade in animals and animal products. Today, its mission also includes the adoption of standards in the field of animal health. The OIE now calls itself the World Organization for Animal Health. OIE standards are adopted by consensus following a process in which specialist commissions draft the standards. The standards are not binding on governments. Private actors participate in the process through national delegations. The OIE lacks sophisticated procedures for NGO participation. 
4. International Organization for Standardization (ISO). ${ }^{27}$ The ISO was established in 1947 to promote international standards in all fields (except those covered by the IEC). The ISO is not an intergovernmental organization. The members are national standard-setting bodies that are the most representative of standardization within each country.

ISO standards are developed through a lengthy process that seeks to define the best standard and to build consensus around it. Today, the ISO has about 12,000 standards. Typically, an industry suggests the need for a standard to the national ISO body. The actual work is done through the 2850 technical committees or sub-entities which are open to participation by industry, research institutes, governments, consumer bodies, international organizations, and international NGOs. Each year, about 30,000 specialists participate in ISO projects. In its strategic plan for 2002-04, the ISO has committed to improve participation by small and medium enterprises, and to strengthen cooperation with international, regional, and national consumer organizations wishing to support the ISO's objectives.

For any particular standards project, the members of the ISO decide whether they want to be Participating, an Observer, or a Non-Member of the effort to devise the standard. The ISO has detailed rules to afford procedural fairness when considering standards. When voting occurs, the draft standard must be approved by two-thirds of the ISO members that have actively participated in the process and three-quarters of all members who vote.

Beginning a decade ago, the ISO added an important environmental dimension to its work. In addition to its technical standards on environmental monitoring, the ISO initiated the ISO 14000 series on environmental management. This work is carried out in Technical Committee TC207.

\footnotetext{
${ }^{27}$ To symbolize the harmonization mission, the founders of the Organization chose the name ISO which is derived from the Greek word "isos" meaning equal. The use of ISO also avoided the problems of other international organizations in which the acronym differs in each language.
} 
Among the best known standards are ISO 14012 on the qualifications of environmental auditors, ISO 14020 on environmental labeling, and ISO 14040 on life cycle assessment.

Adoption of these ISO 14000 standards by companies varies geographically. Over half of the certified facilities are in Western Europe and around 37 percent are in the Asia Pacific region. North America accounted for only five percent of certifications in 1998. The rest of the world had the remaining six percent. In a study of barriers to adoption of ISO 14000 in the United States, Magali Delmas concludes that many companies believe that the U.S. regulatory environment makes it costly for them to adopt such standards. ${ }^{28}$ So far, the WTO has taken no action to promote adoption of ISO 14000 in WTO member countries, either in the TBT Committee or in the Committee on Trade and Environment.

A recent study of the ISO 14000 process by Naomi Roht-Arriaza makes several important findings. ${ }^{29}$ One is that the participants in the TC207 committee are heavily concentrated in large global industry, and that small business, consumer, and environmental groups remain underrepresented. Another is that in some countries (e.g., South Korea), ISO certification for a company might remove regulatory burdens. This provides an incentive to be certified.

\section{International Organization of Legal Metrology (OIML). The OIML was established in}

1955 to set recommendations for measuring instruments. The members are governments. Under the OIML treaty, the governments adopt decisions by a four-fifths vote and then governments are "morally obliged" to implement such recommendations. ${ }^{30}$ The main participants in the process are national regulators and manufacturers of measuring instruments. The OIML provides funding to

\footnotetext{
${ }^{28}$ Magali A. Delmas, Barriers and Incentives to the Adoption of ISO 14001 by Firms in the United States, 11 DUKE ENVIRONMENTAL LAW \& POLICY FORUM 1 (2000).

${ }^{29}$ Naomi Roht-Arriaza, The International Organization for Standardization: Drafting of the ISO 14000 Series, in THE GREENING OF TRADE LAW 251 (Richard H. Steinberg ed., Rowman \& Littlefield, 2002).

${ }^{30}$ Convention Establishing an International Organization of Legal Metrology, 12 Oct. 1955, art. VIII.
} 
facilitate participation by developing country representatives. The process of developing OIML standards appears to be fairly open.

6. Organisation for Economic Co-operation and Development (OECD). The OECD is an intergovernmental organization established in 1962. Among its many activities, the OECD proposes standards in discrete areas and promotes better sectoral policies. For example, the OECD has prepared Guidelines for the Testing of Chemicals and for the mutual acceptance of data. The OECD also has a Scheme for the Application of International Standards for fruits and vegetables; these are grade standards, not health standards. Another OECD initiative is Principles of Corporate Governance. Some of the OECD standards are specifically focused on trade-for example, the scheme for the Control of Forest Reproductive Material Moving in International Trade. This is a process-based system that aims to ensure that seeds are accurately labeled.

The OECD also works with industries to develop informal commitments. For example, the OECD has promulgated a Statement of Environmental Commitment by the Insurance Industry. It is interesting to note that one of the points in this Statement is: "We recognize the precautionary principle, in that it is not possible to quantity some concerns sufficiently, nor indeed to reconcile all impacts in purely financial terms."

All OECD standard-setting activities are carried out in inclusive processes. Generally, governments use expert groups that consist of government officials, academics, analysts from industry, and other appropriate NGOs. The OECD has formal advisory committees from business and from trade unions. In addition, the OECD was one of the first international organizations to put proposals on its website for public comment.

7. Codex Alimentarius Commission (“Codex”). Codex was established in 1962 to set food standards. Today, there are over 4800 of such standards - including commodity standards (e.g., sugar), residue standards (e.g., a maximum residue level), and guidelines for goods practices (e.g., 
risk assessment). The approved standards are submitted to governments for their acceptance. Codex does not require its member governments to implement these standards in domestic regulations.

The process of standard-setting starts with a government's suggestion that a standard is needed. This task goes to a Codex subsidiary body that will draft the standard, working with the Codex Secretariat, and circulate it to governments for comment. Numerous observers in the process are also permitted to provide comments - the observers could be international organizations or NGOs. Furthermore, the government delegations to Codex meetings will sometimes include individuals from the private sector. For example, at a recent meeting of the Codex Committee on Food Hygiene, the Netherlands delegation included an individual from Unilever and the Thailand delegation included an individual from the Thai Frozen Foods Association. ${ }^{31}$ At the end of the process, the standard is adopted by the Commission which meets every two years. The Commission attempts to approve standards by consensus, and typically does, but votes can be taken based on a majority rule.

Since the advent of the WTO, Codex decisions have become more controversial and votes have been taken, sometimes by secret ballot. This occurred in 1995 with a standard for a maximum residue level for growth promoting hormones. In 1996, Codex adopted a standard for natural mineral waters on a close vote. ${ }^{32}$ The possibility of enforcement of Codex standards by the WTO has heightened prior levels of engagement in the process. Codex standards are relevant for both TBT and SPS rules.

\footnotetext{
${ }^{31}$ Codex Alimentarius Commission, ALINORM 03/13 (2001).

${ }^{32}$ Terence P. Stewart \& David S. Johanson, The SPS Agreement of the World Trade Organization and International Organizations: The Roles of the Codex Alimentarius Commission, the International Plant Protection Convention, and the International Office of Epizootics, 29 SYRACUSE JOURNAL OF INTERNATIONAL LAW \& COMMERCE 27, 40-46 (1998).
} 
Although the tiers of the Codex process are formally open to participation by consumer groups, many commentators characterize the process as insular between government and business. For example, David Victor has contended that “... participation in the committee and Commission meetings has been open to any stakeholder, yet only rarely have consumer and other public interest groups attended the committee meeting where standards are elaborated." ${ }^{33}$ Victor goes on to say that "The process is driven by industry, and the vast majority of Codex standards attract essentially no attention from other interest groups."

In addition to its specific standard-setting, Codex has also developed a Code of Ethics for International Trade in Food. This is a Code for governments. For example, it states that no food should be in international trade which is poisonous, harmful or otherwise injurious to health (art. 5). The WTO itself has no similar standard for food trade. Generally, WTO rules do not prescribe the attributes of traded goods, but TRIPS is an exception to that, in calling for governments to cooperate with each other to eliminate international trade in goods infringing intellectual property rights (art. 69). The Code of Ethics is under review at Codex this year. ${ }^{34}$

In April 2002, the WHO and FAO began an evaluation of their Joint Food Standards Programme, including the Codex Alimentarius Commission. Notably, the two U.N. agencies have asked public comments on a set of questions. One of the questions is on the opportunities for developing countries to participate in the Codex process. Another question is on the implications for developing countries if food standard-setting for international trade was allowed "to become the preserve of the developed countries and main trading nations."

\section{Conclusion}

\footnotetext{
${ }^{33}$ David Victor, The Sanitary and Phytosanitary Agreement of the World Trade Organization: An Assessment after Five Years, 32 NEW YORK UNIVERSITY JOURNAL OF INTERNATIONAL LAW AND POLITICS 865, 886 (2000).

${ }^{34}$ Codex Alimentarius Commission, XC/GP 02/5 (2002).
} 
Adopting international standards has an enormous potential for promoting efficiency and economic growth. But the assymmetries of participation can lead to imbalanced results. When richer, larger countries dominate the standard-setting processes, it is possible that such standards can exacerbate the gap between industrial and developing countries. Because of the many ways that it endorses international standards, the WTO can amplify the effects of international standards on trading patterns. Thus, greater attention to the WTO's interface with international standards is needed.

At this point, we do not know how international standards are affecting the generation and distribution of income. We also do not know what impact the WTO is having on adherence to international standards. What we do know is that the WTO has boosted interest in international standards and on the organizations that set them. We also see the WTO reaching out to set norms for standard-setting organizations located within countries and transnationally.

Concern exists about the way that WTO rules may transubstantiate voluntary standards into mandatory ones. The organizations discussed in Part VI produce non-binding standards, and yet various WTO agreements may induce governments to follow them. If that occurs, what will be the effect on the standard-setting organizations? Already, as noted above, the standards process in Codex has become more contentious.

It is easy to imagine ways in which the influence of the WTO could promote use of international standards in order to achieve more sustainable development. ${ }^{35}$ The standards set by the Marine and Forest Stewardship Councils are examples. At present, however, the WTO is not considering such an initiative. The forthcoming World Summit on Sustainable Development will offer an opportunity for governments and NGOs to call attention to ways in which the WTO can make greater use of international standards.

\footnotetext{
${ }^{35}$ This assumes that sustainability comes within the TBT definitions of "related processes."
} 
